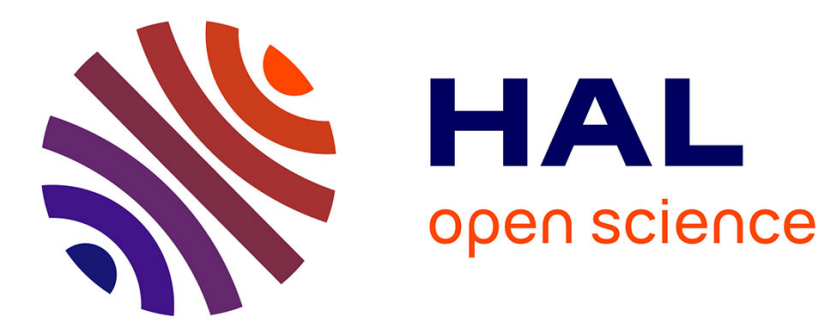

\title{
Apparent insubordination as discourse patterns in French
}

\author{
Henri-José Deulofeu, Jeanne-Marie Debaisieux, Ph. Martin
}

\section{To cite this version:}

Henri-José Deulofeu, Jeanne-Marie Debaisieux, Ph. Martin. Apparent insubordination as discourse patterns in French. Insubordination Theoretical and empirical issues, pp.349-383, 2019. hal-03172591

\section{HAL Id: hal-03172591 \\ https://hal.science/hal-03172591}

Submitted on 19 Mar 2021

HAL is a multi-disciplinary open access archive for the deposit and dissemination of scientific research documents, whether they are published or not. The documents may come from teaching and research institutions in France or abroad, or from public or private research centers.
L'archive ouverte pluridisciplinaire HAL, est destinée au dépôt et à la diffusion de documents scientifiques de niveau recherche, publiés ou non, émanant des établissements d'enseignement et de recherche français ou étrangers, des laboratoires publics ou privés. 


\title{
Apparent insubordination as discourse patterns in French ${ }^{1}$ \\ Jeanne-Marie Debaisieux - LATTICE - Université Sorbonne Nouvelle Paris3 \\ Philippe Martin - LLF- Université Paris 7 Paris Diderot \\ Henri-José Deulofeu Université d'Aix-Marseille
}

\begin{abstract}
In current syntactic literature, two empirical situations are typically earmarked as cases of "insubordination". Their common trait is that, despite formal features that should technically define them as subordinate clauses (they are preceded by subordinators - a subordinating conjunction or some other appropriate morpheme), they behave in discourse like "independent sentences". This description takes into account both formally subordinate clauses functioning as independent discourse units (Evans 2007) and peripheral subordinate clauses which display "main clause features" (Debaisieux 2013, Chap 2). Our stance is that, in both cases, the concept of "insubordination" is an artefact of sentence type theory (Struckmeier \& Kaiser, 2015). Committed to the pioneering model of Claire BlancheBenveniste (1990), which posits a fundamental distinction between grammatical syntax on the one hand and discourse syntax on the other, Desbaisieux (2016) has conclusively shown that, in actual fact, neither of the structures identified in the macrosyntactic paradigm as candidates for "insubordination" - peripheral clauses with main clauses features - are in any way governed by the so-called "main clauses" with which they are combined. In this paper we deal with two types of apparent exclamative insubordinates in French introduced respectively by the subordinating conjunctions si and quand. We argue by extending syntactic dependency to discourse that both are regular syntactic patterns.
\end{abstract}

\section{Keywords:}

Insubordination, syntax, French, discourse patterns

\section{Introduction}

In linguistic literature, two different "sets of facts" have been identified as cases of insubordination. What they have in common is that, according to the mainstream paradigm in linguistic research, a clause formally marked as subordinate (by a conjunction or a dedicated verbal morpheme) behaves in the discourse as a main clause. This definition subsumes, on one side, the case of a formally subordinate clause behaving as an independent discourse unit

\footnotetext{
${ }^{1}$ We are grateful to the editors and two anonymous reviewers for their help in improving a first version of this chapter
} 
(Evans 2007), and, on the other side a peripheral subordinate clause displaying "main clause phenomena" (Debaisieux 2013, chap. 2). Our contention is that in both cases the descriptive tool of insubordination is an artifact. Following the pioneering work of Blanche-Benveniste (1990), Debaisieux (2016) shows that within a paradigm that distinguishes between grammatical and discourse syntax, the macrosyntatic paradigm, peripheral clauses with main clause phenomena are autonomous discourse units pragmatically and not grammatically dependent on the "main" clause they are combined with.

In this paper we will focus on clauses at first sight pertaining to more prototypical cases of insubordinate structures along the lines of Evans (2007). After a detailed description, we will conclude that they can be explained with descriptive devices other than insubordination. To reach such a result, we will take advantage of a general hypothesis put forward by our paradigm: subordinating conjunctions as well as other so called subordination markers are polyfunctional units involved in grammatical dependency as well as in discourse or pragmatic dependency. Let us give an example of the structures we are to deal with.

Spontaneous spoken French corpora provide various examples of utterances that could formally be considered as main clause free subordinates:

(1) la tante avec le petit chapeau et le panier dans le bras / il a fallu qu'elle range tout ça qu'elle nettoie tout ça/elle était pas très contente/mais si tu savais ce que moi j'étais contente

' my aunt with her little hat and basket in her arms she had to put all this stuff in order she had to clean up all that she was not very happy but if you imagine how happy I was' [CRFP]

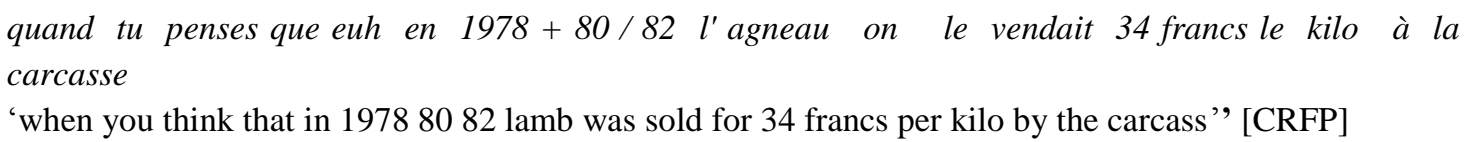

These examples, according to standard analyses, display structures that should formally be connected to a main clause, but which behave here as autonomous statements. These constructions can be considered formally subordinate, as they are introduced by a subordinating conjunction. However, they stand as isolated discourse units that are impossible to link syntactically to what precedes or follows. No main clause can be found in the context that could govern the subordinate clause. They also form independent prosodic units.

The main goal of this paper is to show that it is possible to account for these constructions not as irregular instances of syntactic structures but as an expected result of the way grammar and discourse interact in licensing linguistic forms.

To do so, we will organize our paper by confronting the analysis proposed by Evans (2007) in terms of insubordination, i.e. 'the conventionalized main clause use of what, on prima facie grounds, appear to be formally subordinate clauses' with an alternative analysis based on the framework of the Approche Pronominale (Blanche-Benveniste et al (1990), Debaisieux (2007, 2013, chap 3, 2016), Deulofeu (2008, 2010, 2014) among others.) which, instead of resorting to the problematic device of ellipsis, proceeds by extending the scope of syntactic description to the wider domain of discourse units.

The paper is organized as follows. In section 1, we give a detailed corpus-based analysis of the prosodic, syntactic, semantic, and pragmatic properties of the apparent insubordinates in (1) and (2). This description highlights that both constructions share many 
common properties but that they additionally obey specific constraints that we deal with separately in section 2. example (1) can be analyzed as a construction that associates a siclause functioning as a pragmatic marker with a main clause of the exclamative type. example (2) is closer to prototypical cases of insubordination in as much as it involves a complex clause introduced by the subordinating conjunction quand without a possible main clause. Nevertheless we will show that this clause does not display the internal properties of a prototypical subordinate, being closer to clauses fulfilling a meta-discursive function within a discourse pattern. In section 3, we show that an analysis following the steps of Evans insubordination model faces serious difficulties in dealing with both constructs.

Finally, we show in section 4 how the descriptive generalizations can be captured within the Approche Pronominale framework, which assumes that grammatical and discursive relations combine to build up utterances and, consequently, that the apparent insubordinates are instances of regular syntactic patterns. The spoken data used in this analysis are extracted from two corpora: the TCOF Corpus, collected in the French city of Nancy and the corpus CRFP compiled at Aix en Provence University. The size of the whole data base is about 1 million words representing several spoken genres. The spoken examples are edited without punctuation marks according to the source conventions. The fiction data are extracted from the Frantext database (http://www.frantext.fr/), a resource containing more than 1500 texts of fiction.

\section{Characteristic properties of the patterns si tu savais... and quand je pense...}

From an overview of the observed properties, we can provisionally regroup (1) with (2). Broadly speaking, both share many properties with independent exclamative clauses. In order to take sufficient relevant data into account, we will expand our corpus of spontaneous spoken French findings with examples from the Internet and written fiction.

\subsection{Prosodic properties ${ }^{2}$}

In example (1), si tu savais ce que moi j'étais contente ends with a conclusive prosodic contour characterizing independent declarative clauses in French. As shown in Fig. 1, we observe a falling melody (fundamental frequency F0) on the second occurrence of the word contente:

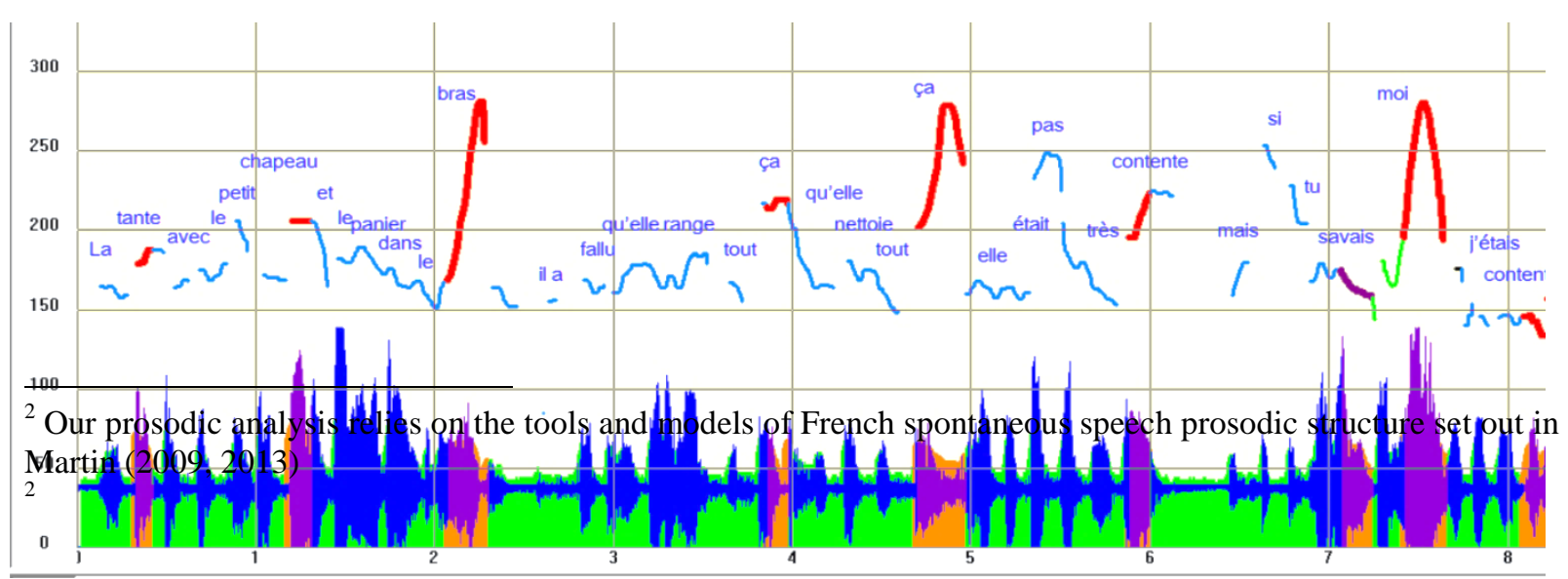




\section{Fig. 1. Prosodic analysis of example (1)}

(1) La tante avec le petit chapeau et le panier dans le bras il a fallu qu'elle range tout ça qu'elle nettoie tout ça elle était pas très contente mais si tu savais ce que moi j'étais contente [CRFP]

'my aunt with her little hat and basket in her arms she had to put all this stuff in order she had to clean up all that she was not very happy but if you imagine how happy I was'

We can also observe on the word moi a specific prosodic contour with a contrastive focus interpretation, which is found only in main clauses.

In (3), we find again the conclusive prosodic contour of an autonomous statement with an exclamatory value in the insubordinate si clause, as can be seen in Fig. 2 which displays a subpart of the clause: ${ }^{3}$

(3) bon ben ils font des trucs //si tu savais ce qu' elle fait / elle fait plein de stages / elle fait euh assistante de metteur en scène [CRFP]

'well they do stuff // if you knew what she does / she does a lot of internships / she uh is assistant director'

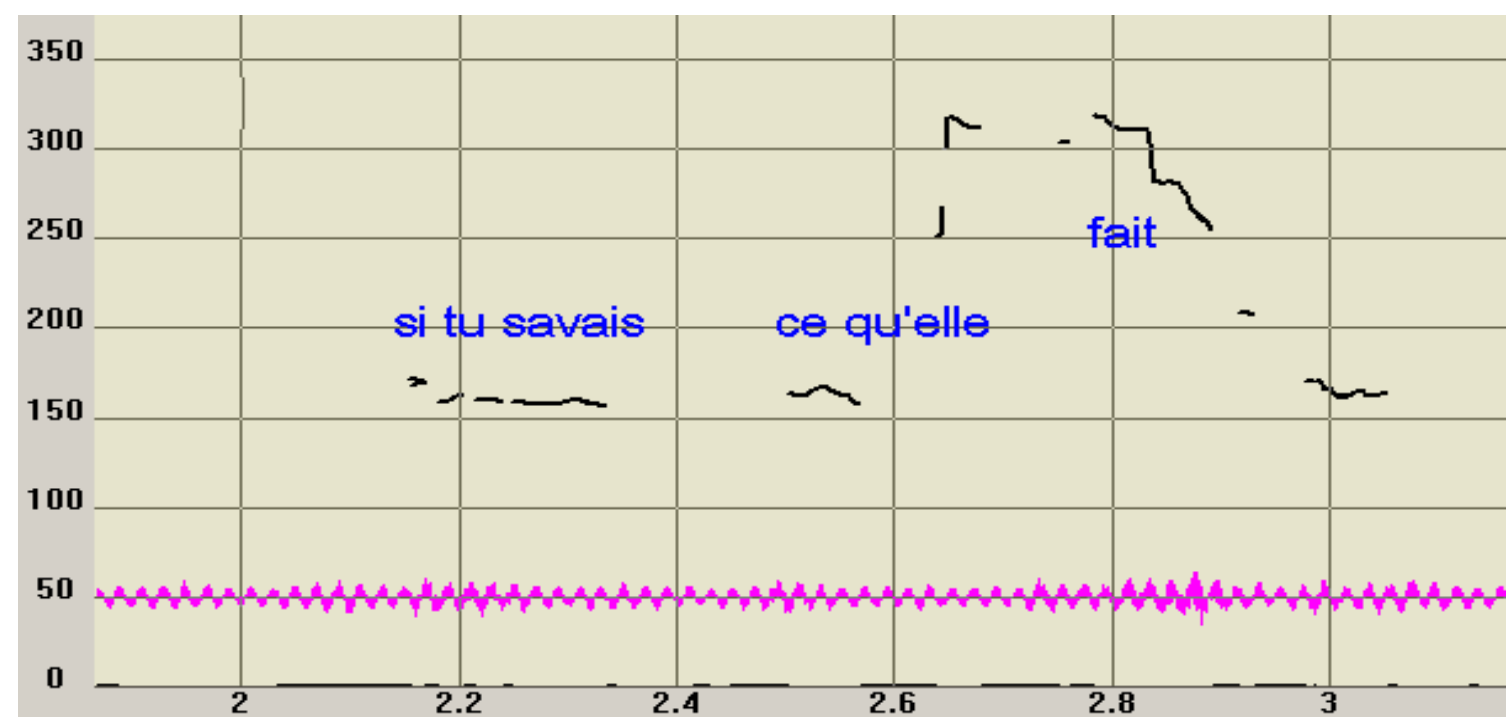

Fig. 2. Prosodic analysis of subpart of example (1)

(3) si tu savais ce qu'elle fait 'if you knew what she does'

Fig. 2 shows the characteristic property of conclusive contours: F0 falling on the last syllable. The exclamative conclusive contour can be distinguished from a mere assertive contour by the presence of a hump on elle before the falling melody.

As regards quand (je/tu) penses que clauses, many occurrences found in our corpus show an assertive conclusive contour instead of the expected exclamative one. This is

3 Notice that this terminal contour instead of a continuative contour undermines the analysis of the si clause as subordinated to "elle fait plein de stages". 
observed in Fig. 3, in which the excerpt from Example (2) shows the lack of a hump before the falling F0 on carcasse.

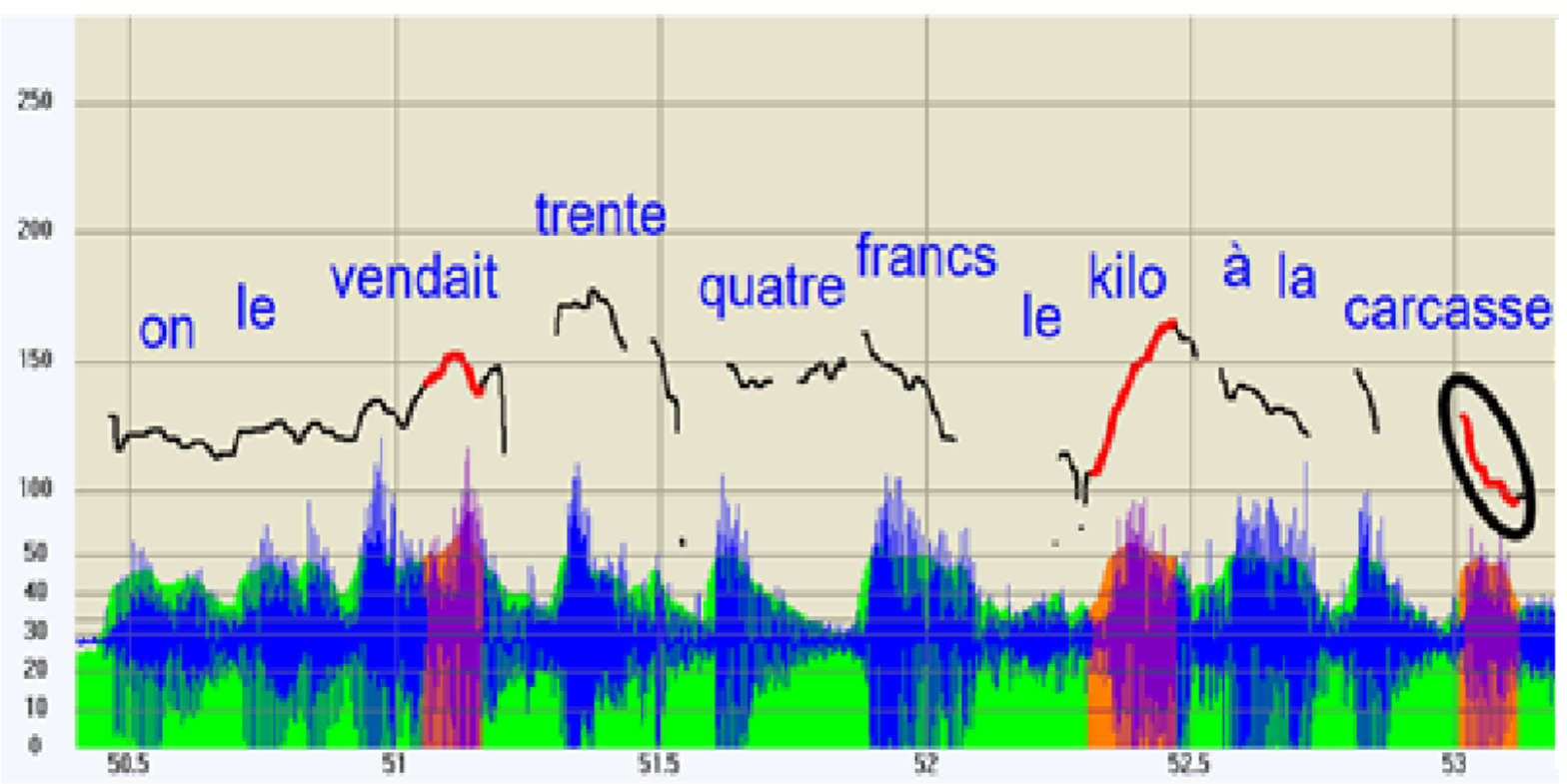

Fig. 3. Prosodic analysis of subpart of example (2)

(2) quand tu + penses que euh en mille neuf cent soixante-dix-huit (hum) quatre-vingt quatre-vingt- deux + euh l'agneau + on le vendait trente-quatre francs le kilo à la carcasse [CRFP]

'when you think that in 19788082 lamb was sold for 34 francs per kilo by the carcass'

The prosody of the examples confirms their status as independent clauses. Furthermore, if isolated from the context with a sound editor, they appear prosodically complete (i.e. no further sequel is expected by listeners to complete the sentence).

\subsection{Syntactic properties}

Numerous formal cues support the independant clause status of these constructions. As regards the external links, the following examples show that they cannot be involved in any kind of dependency. In example (4), we note a feedback discourse particle hein "isn't it" that never appears between a subordinate and a main clause.

(4) speakers are referring to the stand-off between students and the Government about plans to institute non-binding work contracts for first-time under 26 year-olds.

moi je pense qu'ils [les étudiants] sont assez euh + assez mordus et assez dans le coup pour pas se laisser faire / quand tu penses que déjà euh il [le gouvernement] a reculé hein oh non ça c'était pour te dire $[\mathrm{TCOF}]$

'But as for me I think that they are involved enough and aware enough not to accept things passively / when you think that he has already backed down isn't it oh no this was just to say'

Furthermore, the non-clausal fragment oh non could not provide a possible governor for the quand clause. Notice that, even if these clauses are followed by a plain declarative clause, it is often impossible to consider the following clauses as main clauses to which the $s i$ or quand clauses could be subordinate. Consider example (3), repeated here as (5): 

assistante de metteur en scène // [CRFP]

'well they do stuff // if you knew what she does / she does a lot of internships / she uh is assistant director'

The autonomous status of the clause is, independently of the prosody, highlighted by the incorrect semantic interpretation which would result from considering elle fait plein de stages as the main clause of the si clause as shown in (5'):

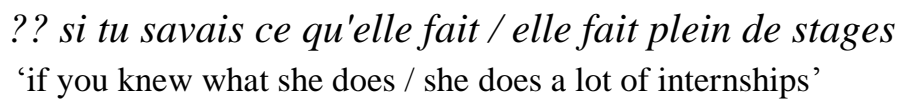

However the semantic interpretation becomes perfect if we assume that si tu savais ce qu'elle fait is a main exclamative clause in which the ce que pronoun has an intensive value "what an amount of things is she doing". The following clause elle fait plein de stages may be analyzed as an independent assertive clause justifying the 'exclamative' stance conveyed by the insubordinate.

As far as their internal structure is concerned, we can point out the presence of 'main clause phenomena' related to message organization, that is main clause phenomena of type 2, according to Verstraete's (2007) classification ${ }^{4}$ Such structural remodelings are predominantly found in main clauses. We note for instance the topicalized moi in (1) moi j'étais contente conveying a narrow focus effect, or the topicalisation of agneau in (2) combined with a detached focussed adjunct à la carcasse.

Similar phenomena are found in examples from written fiction. For example, (6) displays a complex information structure organization: a topicalized constituent de nous deux combined with a focalisation on moi by means of a cleft sentence:

\section{Quand je pense que, de nous deux, c'est moi qui passe pour un sale caractère! 'To think that, out of the two of us, it's me who is considered the bad-tempered guy!' [COLETTE, Sept dialogues de bêtes, 1905. ]}

These constructions must be analyzed as stand alone clauses. As for their clause type, we will follow the proposition of Marandin (2008), who posits for French an exclamative clause type characterized by a set of criteria that distinguish it from declarative and interrogative ones. We will show that the constructions we are analyzing meet these criteria and therefore are instances of the exclamative clause type. Thus, Like other exclamative clauses, they cannot combine with evidential adverbs:

(7) *à mon avis si tu savais ce qu'il m'a dit!

(8) *à mon avis quand je pense que ... !

in my opinion if you knew what he told me!'

* à mon avis qu'il est beau! 'in my opinion when you think that ... ! "” 'in my opinion how handsome he is!'

Indeed if we follow the evidential approach of Marandin (2008) which "captures the expressive flavor of exclamatives without arbitrarily assuming that they have to express an

\footnotetext{
${ }^{4}$ Verstraete (2007:179) : "The second category of main clause phenomena relates to the organization of the message in the secondary clause: preposing of the VP, negative adverbial or negative NP marks discursive prominence for the element in Question”.
} 
emotive attitude, and in particular, surprise" we can understand that they "are incompatible with overt perspective markers" that could be redundant with the "ego-evidentiality" (speaker based) force characteristic of exclamative illocution (Garrett 2001). As well, ego-evidentiality entails that the addressee cannot be directly called on. Hence the incompatibility of exclamatives with tags like tu sais 'you know', whose function is to call upon the addressee for collaboration:

(10) ?? ce qu'il est beau tu sais

(11) *quand je pense que ... tu sais "how beautiful it is you know'

'when you think that ... you know !'

As exclamative main clauses, these constructions cannot serve as answer or reply to questions:

A Paul est-il intelligent?
$\mathrm{B} *$ si tu savais ce qu'il est intelligent "is Paul smart?'

'if you knew how smart he is!'

We can also point out that we find mainly evaluative vocabulary, such as subjective adjectives like contente 'happy' inside the copular construction in (1), the verb reculer ' back down' in (4) that here does not refer to an actual movement but is an expressive way to signal a defeat, and the word chantier in (15), which literally means 'warehouse', but here does not refer to an actual works site and instead has the evaluative meaning of 'mess'. We find also scalar expressions, forming the basis of judgments of high degree, as the scale of price of the lamb is easily inferable in (2).

Now it is important to point out that even as these exclamative clauses meet the characteristic properties of clauses used in exclamative utterances, they display additional ones that make them a specific subtype. These clauses si tu savais/avais vu show only instances of main verbs of cognition and perception (savoir, voir) with si. With quand we likewise find, first and foremost, verbs expressing belief or opinion: savoir, penser or perceptual verbs such as voir or entendre.

These restrictions can be related to "the fact that exclamatives are selected by verbs describing an experience of the content, be it perceptual or mental" (Marandin 2008). As for their grammar, the tense must convey an irrealis meaning ( $S i+$ anperfect with voir, imperfect with savoir), (Quand + only imperfect and present tense). Subjects are restricted to the clitic pronouns je, $t u$ or on - and bear in mind that the 'indefinite clitic' on, generally interpreted as a first person plural, can include the point of view of the speaker. These restrictions may be linked to the fact that in standard exclamatives the evidentiality source is the direct knowledge or perception of the speaker. Third person subjects, as in (1'), shift the meaning towards a suspended interpretation:

Likewise (13), with a lexical subject, is not a possible exclamative and can only be taken as a suspended temporal quand clause: 
These lexical and person constraints combine with more subtle syntactic ones. In these constructions the verb cannot be modified by an adjunct phrase. In (14), excerpted from (4) above, inserting adjuncts, as in (13'), renders the utterance quite unacceptable:

(14) mais moi je pense qu'ils sont assez mordus et assez dans le coup pour pas se laisser faire quand tu penses que déjà il a reculé hein

'when you think that has already backed down' [TCOF]

(14') ?? quand tu penses sérieusement / un instant que déjà euh il a reculé hein 'when you think seriously / for a moment that'

A similar example is (15). Again, inserting an adjunct, as in (15'), severely degrades its acceptability:

(15) ah ben il a bouché toutes les voies hein tous les wagons se sont achevalés l'un sur l'autre si tu avais vu le chantier

"well it (the train involved in the accident) blocked all the tracks isn't it all the carriages ended one over the other if you could have seen that mess' [TCOF]

(15') ?? ah ben il a bouché toutes les voies hein tous les wagons se sont achevalés l'un sur l'autre si tu avais vu précisément/ en compagnie de Jean le chantier

'if you could have seen precisely / with John that mess'

These facts suggest that in these clauses the verbs do not fulfill the function of fullfledged governors and are devoid of denotative meaning, such as we find in their uses as parentheticals. There is additional evidence that the clauses following si tu savais are not in fact governed by the verb. First, savoir in insubordinates combines with exclamative clause types that are not possible complements in other contexts:

C'est pour lui que j'ai quitté la France... car si tu savais qu'il est beau que son regard est enivrant et que sa voix a de charme!

It is for him that I left France ... because if you knew how handsome he is, how intoxicating his eyes are and how charming is his voice!' [forum.aufeminin.com $>$... > Ruptures et deceptions amoureuses]

The apparently embedded exclamative que sa voix a de charme, is normally found only as a free-standing exclamative clause. Savoir without si cannot take these clauses as complements as shown in (17):

*Pierre sait que ma voix a de charme

'Peter knows how much my voice is charming'

Insubordinated savoir conditionals can also combine with clauses that Milner (1978:259) calls 'indirect exclamatives', as in (18) excerpted from (1) above:

$$
\begin{aligned}
& \text { si tu savais ce que moi j'étais contente } \\
& \text { 'if you imagine how happy I was' }
\end{aligned}
$$


But all indirect exclamatives can function as direct ones, except the one introduced by the degree complementizer que. If we take into account example (16), the following descriptive generalization emerges: si tu savais exclamative insubordinates can combine with all types of direct exclamatives, including those that are not embeddable under savoir. The logical conclusion that we can draw is that there is no grammatical dependency relationship between si tu savais and the associated clauses. As a consequence, we may propose that the construction consists of two independent clauses with a kind of paratactic link between the two.

Another important conclusion is that only exclamative clauses combine with si tu savais in this construct, whereas savoir regularly subcategorizes other sentence types. This conclusion is in keeping with our analysis of savoir as a verb deprived of a governing function. Indeed the verb savoir in the insubordinate does not display the full range of its possible clausal complements. For instance, in main clauses, savoir takes a declarative (and non-exclamative) clause introduced by the complementizer que as in (19):

But with such complements the insubordinate cannot get the exclamative interpretation as shown in (19'):

(19') ?? si tu savais qu' il est revenu!

'if you knew he returned!'

All these puzzling facts become clear if we split the insubordinate into two subparts: a main exclamative clause combined with a reduced si tu savais clause, fulfilling the function of a pragmatic marker. In the case of quand clauses, there are also specific syntactic structures, which partly depart from the pattern of the si clauses. What they have in common with the $s i$ tu savais clauses is that the insubordinating quand combines with clauses that are not possible complements of the apparent main verb, in particular with indirect exclamatives:

quand je pense ce qu' ils vont se mettre sur la gueule partout ailleurs

'when I think they will fight everywhere else' [https://fr.wikiquote.org/wiki/Kaamelott/Arthur]

quand je pense comme c'est tellement génial quand c' est lui qui decide

'when I think how it's so great when it's he who decides'

[forum.aufeminin.com > ... > Sexualité > Couple - Sexualité \& technique]

This combination of clauses is impossible in other syntactic contexts as shown in (20')

(20') * Pierre pense ce qu'ils vont se mettre sur la gueule partout ailleurs

'Peter thinks they will fight everywhere else'

However, in contrast to $s i$ insubordinates, quand insubordinates accept regular que declarative complement clauses of penser, as in (22) excerpted from (4): 
The conclusion is that insubordinates in quandi je/tu pense(s) split into two distinct structures: one, very similar to the si tu savais construct, in which the ce que introduces a main exclamative and quand je pense is a parenthetical. And another one with quand introducing what looks like an "insubordinate" complex clause in which the que-clause seems to be the embedded complement of pense. We should add that this second type is in fact a construction of its own, in so far as the verb penser does not display the properties of a fullfledged governor, as we will show in the next section. These results raise the following issue: are these constructions merely instances of two entrenched exclamative constructions, or can we derive them from more regular patterns? In order to address this issue, in the next section we will deepen the description of both constructions.

2. Two structures for the apparent "insubordinate" exclamatives

\subsection{The si tu savais clause}

Additional evidence supports the hypothesis that the si tu savais clause is not integrated within the grammar of the exclamative clause. A search through the Frantext database brings to light examples in which the chunks si tu savais/ si tu avais vu can appear alone without the exclamative clause and followed by marks of omission or exclamation:

(23) Si tu savais... mon Dieu... si tu savais... mon Dieu... si tu savais !

If you knew my God if you knew my God if you knew

'If you only knew ... my God ... if you only knew ... my God ... if you only knew!'

[SUE Eugène. Le Juif errant.1845]

In (24), the chunk behaves as an autonomous utterance linked to the following one by the coordinator car, which forbids any grammatical dependency:

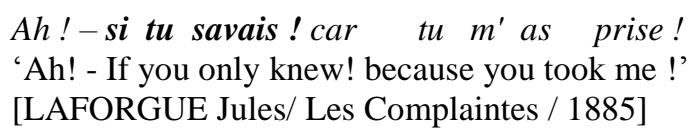

When grouped with a main utterance, many cues show that the two are not integrated in their grammatical structure. In (25), the clause appears just inserted as a parenthetical inside a noun phrase between the head and a detached adjunct:

(25) c'était d' un curieux... il y avait une vitrine de bijoux... un collier de perles noires

entre autres... si tu avais vu! ... à trois rangs...

'It was so strange ... there was a jewelery shop window ... a black pearl necklace among others ... if you had seen! with three rows ...'

[Edmond de GONCOURT Jules de, Renée Mauperin, 1864, p. 181]

In (26) it appears as an appended parenthetical chunk after the main clause:

(26) J'ai le coeur si plein de toi, si tu savais !

'I 've my heart so full of you, if you only knew!'

[SAMAIN Albert / Le Chariot d'or /1900] 
The grammatical independence of the chunk is underlined by the fact that it is not necessarily associated with a main verb. Consider for instance example (27), in which the topical non clausal fragment cannot be a governor:

oh! Les autres, si tu savais!

'oh! The others, if you only knew'

[ZOLA Émile / La Bête humaine / 1890]

We could easily use this pattern to modify example (15):

$\left(15^{\prime}\right)$

mais le chantier si tu avais vu

In the front position, the idiosyncratic status of the chunk is highlighted by a high degree of variation in the punctuation marks separating it from the accompanying clauses. Besides the marks of omission or exclamation noted before, we find a comma in (28):

Si tu savais, je t' aime!

'If you only knew, I love you!'

[HUGO Victor / Théâtre en liberté : Mangeront-ils ?/1867]

And strangely enough a colon in (29):

O mon vieux Brèchemain, si tu savais: il arrive! il arrive!

'O my old Brèchemain, if you only knew: he arrives ! he arrives !'

[DAUDET Alphonse / Les Absents]

This variation shows that the writers are struggling with the challenge of expressing by punctuation what they feel to be an unusual relationship between the constructions.

All these facts support a syntactic analysis that does not require an "insubordination" framework. Its si tu savais part can be analyzed as a construction of its own. As it is emancipated from syntactic dependency it behaves as a mobile autonomous phrase available for pragmatic functions that we will specify later. In sum, it shares many properties with members of the syntactic category of discourse parentheticals including marked clauses like si tu veux 'if you like', si je peux if I may', as well as 'bare' ones like tu vois 'you see', tu sais 'you know', je veux dire 'I mean', fulfilling the same pragmatic functions as epistemic and evidential adverbs. This parenthetical is combined with a regular exclamative main clause.

\subsection{The quand je pense clauses}

For the quand clause, an analysis as a segment not integrated in the grammar of the associated clause fits in very well with examples such as (30):

(30) Bon de toutes façons, c'est de l'histoire ancienne maintenant le Tb1 ${ }^{5} \ldots$

Quand je pense ce que ça a couté à certains! Ils ont vraiment gaspillé leur argent

'Well anyway, that's ancient history now the Tb1... When I think of what it has cost

some people! They really wasted their money'

[www.photoetmac.com/2014/06/du-raid0-en-thunderbolt-2-aller-vite/]

\footnotetext{
${ }^{5}$ Thunderbolt One (Computer technology)
} 
In (30), the associated clause cannot be analyzed as a complement of penser as shown in $(30$ '):

(30') *Pierre pense ce que ça a coûté à certains

'Pierre thinks of what it has cost some people!'

Neither can the whole insubordinate be analyzed as subordinate to ils ont vraiment gaspille leur argent. The same syntactic autonomy can be observed in the following examples in which the lack of the complementizer que reveals a paratactic link, in French literary style (31) or modern French (32):

(31) Quand je pense il n'y a pas six mois nous dansions de si bon coeur à la Vote de Cassis! 'When I think about it not six months ago we danced so heartily at the Vote in Cassis!' [DAUDET Alphonse, Lise Tavernier, 1872, p. 264]

(32) Quand je pense il y a juste 3 semaines j' ai encore fait un aller retour en avion Bruxelles Nice sans présenter une seule fois une pièce d'identité!

'When I think about it just three weeks ago I made another round trip flight Brussels Nice without showing an ID once'

[www.instinct-voyageur.fr/8-facons-de-rater-lavion-et-son-voyage-mes-c.]

The construction quand je pense can even appear as an isolated unit as in (33):

(33) Quelles maîtresses, mon Dieu !... Et Jenkins pour seul protecteur...

Oh! quand je pense... Quand je pense...

'What mistresses, my God ... And Jenkins as sole protector ... Oh! When I think...When I think ...' [DAUDET Alphonse, Le Nabab, 1877, p. 574]

Nevertheless, the quand je pense clause shows a lesser degree of independence than observed with si tu savais. It never appears inserted or postposed to the associated clause and its uses as an isolated clause are in fact not very numerous: 16 occurrences out of 1315 "insubordinates" were returned in our search, whereas we get 126 occurrences of isolated si tu savais out of 804 "insubordinates" in Frantext.

In any case, even if the main clause + parenthetical analysis is suitable for to the examples with quand je pense combined with overt exclamative clauses, it cannot be used for the quand je pense que + declarative case. For this case, the most frequent in oral style, an insubordination analysis could be supported by the strong links between the insubordinate quand je pense que and the use of the clause in plain subordinates. In order to specify this link, we must distinguish two types of apparently subordinate quand clauses.

We certainly find examples in which the construction quand je pense que can be analyzed as a regular adjunct integrated into the syntactic structure of a following main clause as a dependent of the main verb ${ }^{6}$ :

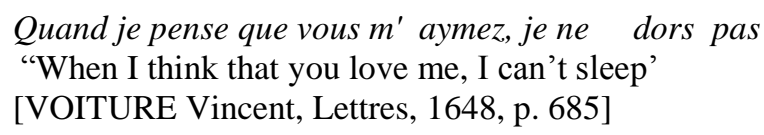

Such an adjunct can be postponed to the main clause, as shown in (35):

\footnotetext{
${ }^{6}$ The usual semantic interpretation of this adjunct is as a time modifier, but other interpretations of this syntactic structure are possible, for instance a conditional one.
} 
Je me porte bien quand je pense que vous vous préparezà me venir voir.

'I feel well when I think that you are preparing to come and see me'

[SÉVIGNÉ Mme de, Correspondance : t. 2 : 1675-1680, 1680, p. 349]

Another syntactic test can confirm the adjunct status of the construct: it can be used as an answer to a clause containing the time $w h$-interrogative pronoun quand ${ }^{7}$ :

(34') Quand est-ce que je ne dors pas? Quand je pense que vous m'aimez

'When is that I do not sleep? When I think that you love me'

(35') Quand est-ce que je me porte bien? Quand je pense que vous vous préparez à me venir voir.

'When is it that I am well? When I think that you are preparing to come and see me.'

But in numerous examples, an analysis of the construction as an adjunct integrated in the grammatical structure of the main clause is impossible, either in contemporaneous speech:

(36) Et quand on pense aux progrès de la médecine depuis 10 ans évidemment c'est merveilleux

'And when you consider the advances in medicine for 10 years, of course it's wonderful'

[CRFP]

or in classical French literary style:

(37) Quand je pense et parle surce sujet, ce sont mes véritables affaires, je n' en connais point d'autr es.

'When I think and speak on this subject, it is my genuine business, I don't know of any others.'

[SÉVIGNÉ Mme de, Correspondance : t. $3: 1680$ - 1696, 1696, p. 740]

In both cases the morpheme quand is disconnected from its grammatical status of conjunction introducing a phrase modifiying the propositional content of the associated bare clause. A compositional interpretation assuming that the quand clause is a canonical time adjunct would lead to an odd meaning (e.g. for 35, the advances of medical science are wonderful at the very moment when you think of them). The necessary non-compositional semantic analysis of these examples is corroborated by a syntactic test: the quand clause cannot be an answer to the interrogative pronoun quand as shown in (37'):

?? Quand est-ce que ce sont mes véritables affaires quand je pense et parle sur ce sujet ....

'When is it the real business when I think and speak on this subject'

These facts undermine an analysis of the quand clause as a dependent time adjunct in (36) and (37). The specific syntactic status of these quand clauses is also supported by their information structure. In (38), it is the clause following the verb penser that has preeminent informational status, in that its content is referred to by the pronoun cela in the 'main clause':

quand je pense que je ne me separe de vous que pour rendre à la

nymphe un service extremément important, cela me sert d' une espece de soulagement

\footnotetext{
${ }^{7}$ A wider set of criteria to distinguish between grammatical and discourse dependency has been addressed in an abundant literature within the framework of the Approche Pronominale, Debaisieux (chap 3, 2016), Deulofeu (2017) among others.
} 
'when I think I am separating you from me to give to the nymph an extremely important service, it serves me as a sort of relief.'

[BARO Balthazar, La Conclusion et dernière partie d'Astrée, 1628, p. 101]

Consider also that (36) could be paraphrased by a dislocated pattern skipping the verb penser:

(36') les progrès de la médecine depuis dix ans c'est merveilleux

'the advances in medicine for 10 years it's wonderful'

These facts are properly accounted for if we consider that quand introduces a metadiscursive clause fulfilling the pragmatic function of establishing a new topic, the commentary on which is provided by the main clause. Insubordinated quand je pense que is clearly related to these metadiscursive peripheral clauses, with which they share the property that the verb is not a full verb, contrary to time adverbial clauses in quand. Another common property is an additional restriction that bears on the subordinating morpheme quand. We could expect that the clause might have been introduced by the literary equivalent of quand, i.e. lorsque, as both can be used interchangeably in canonical integrated temporal subordinates. But this is not the case for the constructions under study here. That is, the lexical constraints are not limited to the main verb but extend to the linking morpheme. From (39) in which quand on pense que is clearly a time adjunct, we can derive (39'):

$$
\begin{aligned}
& \text { Quand on pense que le bonheur dépend beaucoup du caractère, on a raison } \\
& \text { 'When we think that happiness depends a lot on one's character, we are right' } \\
& \text { [VAUVENARGUES, Des lois de l'esprit : florilège philosophique, 1747, p. 114] }
\end{aligned}
$$

(39') Lorsqu'on pense que le bonheur dépend beaucoup du caractère, on a raison

'When we think that happiness depends a lot on one's character, we are right'

The same test applied to the "insubordinate" (40) excerpted from (4) above, gives the unacceptable (40'):

(40) quand tu penses que déjà euh il a reculé hein

'to think that it has already backed down'

(40’) ?? lorsque tu penses que déjà euh il a reculé hein

'to think that it has already backed down'

Nor can lorsque introduce a metadiscursive "subordinate":

(36') ?? lorsque je pense aux progrès de la médecine c'est merveilleux

'when I think of medical advances...'

Taken together, these facts suggest that the insubordinate quand je pense que does not function as a canonical temporal adjunct and must be considered as a specific entrenched construction in a synchronic description of French.

\subsection{Interim conclusion}


So far we have brought to light two different syntactic patterns for the apparent insubordinates (1) and (2). One pattern encompasses all the cases of si tu savais occurrences and minor cases of quand je pense clauses. Under close examination, this pattern does not seem to be related to insubordination. Rather, it consists indeed of an exclamative main clause associated with a si tu savais clause not integrated into the grammatical structure of the main clause. The standard embedding pattern is restricted to the quand je pense que clauses, which therefore remain candidates for an insubordination analysis. But still remains the issue of what type of subordinate underlies the insubordinate: are there former adjuncts or metadiscursive peripherals, and what is exactly meant by "peripheral"? We will see in the next section that the interpretative properties of the patterns support the distinction made on syntactic grounds.

\subsection{Semantic interpretation}

In the exclamative main clause pattern, neither reconstruction nor added material is needed to get a full interpretation. (1) has the meaning of a self-contained exclamatory utterance. This meaning is mainly conveyed by the syntactic main clause: 'mais ce que moi j'étais contente!' 'How happy I was!' As for the si tu savais clause, it does not contribute to the propositional content of the whole utterance but adds an interactive evidential value to the meaning of the exclamative clause. It is indeed expected for syntactically emancipated clauses that they fulfill pragmatic or discourse functions (Verstraete 2007). The pragmatic function of si tu savais is to encode a special type of evidentiality. 'si tu savais' invites the addressee to share the ego-evidentiality that is the source of the exclamative interpretation of the main clause. Look at the two following examples:

.. tes yeux!... si tu savais, tes yeux!...

'your eyes! ... if you knew your eyes'

[BATAILLE Henry/ Maman Colibri / 1904]

Quelle tête!... si tu avais vu sa tête!...

'What a head! ... If you saw her head'

[MAUPASSANT Guy de/Contes et nouvelles, t. 1 : 1885]

In both cases the function of si tu savais/si tu avais $v u$ is to create by means of the irrealis imperfect a possible world in which the addressee could have directly experienced the situation triggering the exclamation, so that he could be in a position to share the egoevidential stance of the speaker.

As for quand je pense que, quand on voit que etc it is also the case that the clause as a whole gets an independent exclamative interpretation. Consider example (43):

(43) quand on voit la place qu' on a fait devant la mairie - c'est une place où il y a plus personne / avant il y avait des un parking il y avait des voitures - donc il y avait une vie quand même avec euh les voitures - maintenant ils ont enlevé toutes les voitures - il y a une belle place - ah ça elle est belle mais il y a rien dessus - c'est un trou à courant d'air -

'when you see the square that was built in front of the town hall - it's a square where there is nobody left / before there was a parking lot there were cars - so there was still a life with the uh cars - now they have removed all the cars - there is a beautiful square - oh it is beautiful - But there is nothing on it - it's a hole for a draft of air' [CRFP] 
The semantic interpretation is perfect if we assume that quand on voit la place qu'on a fait devant la mairie is a main exclamative clause conveying a negative subjective stance to the situation: how outrageous it is to see the square in front of the Town Hall. The following clause justifies the negative stance conveyed by the insubordinate, just as it would have done with regard to a mere fragment bearing an exclamative contour: Alors, la place qu'on a fait devant la Mairie! 'Then (look at) the square they have built in front of the Town Hall' The exclamative stance can be positive as well as negative, as in standard exclamatives. Here, the following context shifts towards a negative stance, since the speaker criticizes the urban policy of the town council, contrasting it with a positive appraisal of the former condition of the square: il $y$ avait une vie quand même ('so there was still a life') which opposes the negative metaphor used to describe the current site: c'est un trou à courant d'air ('it's an airstream hole').

But there is a major difference compared to the main clause + parenthetical patterns. Here it is the quand je pense fragment that triggers the exclamative meaning. The clause introduced by que is a plain declarative clause and in general the prosodic pattern of the whole clause is not exclamative. The quand je pense fragment as a whole has the function of marking the type of the clause as exclamative. The verb penser displays properties similar to those by which Tomasello (2005: 251) defines the 'clausal operators': "the subject is in first/second person, the verb is active [...] without auxiliaries or other accoutrements; the matrix clause is shorter than the dependent clause and can occur in various positions." That amounts to saying that penser is not a full-fledged main verb and can be analyzed as a subcase of clausal operators giving intersubjective or evidential modulation. The verb je pense may alternate with another stance indicator $j e$ vois in the insubordinate exclamatives: it gives the perceptual source triggering the exclamative interpretation of the clause introduced by que.

\section{Analysis : Insubordinated Structures or Discourse Patterns?}

Looking for the best way to give an integrated description of these structures, we will compare two hypotheses within two theoretical frameworks. The first hypothesis claims that the idiosyncratic properties of the two structures result from a diachronic process of reanalysis of canonical sentential structures leading to the emancipation of the formally subordinate clauses: these clauses with properties of independent clauses 'have diachronic origins as a subordinate clause' (Evans 2007). The second hypothesis is that the constructions with si and quand do not result from the emancipation of a former subordinate clause but are genuine pragmatic routines. In the first one, a pragmatic marker si tu savais / quand je pense is combined with a free-standing exclamative. For the quand je pense que clause, we will propose an analysis inspired by the insubordination hypothesis but working at a discourse level

\subsection{The insubordination framework}

Evans (2007:366) uses the term 'insubordination' to refer to "the conventionalized main clause use of what, on prima facie grounds, appear to be formally subordinate clauses." 
This historical process follows four steps which we have set out in the table below excerpted from Evans \& Wanatabe (2016: 3)

\begin{tabular}{|c|c|c|c|}
\hline Subordination & Ellipsis & $\begin{array}{c}\text { Conventionalized } \\
\text { ellipsis }\end{array}$ & $\begin{array}{c}\text { Reanalysis as main } \\
\text { clause structure }\end{array}$ \\
\hline$A$ & $B$ & $C$ & $D$ \\
\hline $\begin{array}{c}\text { Biclausal } \\
\text { construction with } \\
\text { subordinate } \\
\text { construction }\end{array}$ & $\begin{array}{c}\text { Ellipsis of main clause, } \\
\text { any } \\
\text { contaextuallyappropriate } \\
\text { material can be } \\
\text { recovered }\end{array}$ & $\begin{array}{c}\text { Restriction of } \\
\text { interpretation of } \\
\text { ellipsis material }\end{array}$ & $\begin{array}{c}\text { Conventionalized } \\
\text { main clause use of } \\
\text { formally } \\
\text { subordinate clause } \\
\text { (Constructionalization) }\end{array}$ \\
\hline
\end{tabular}

Fig. 4. Historical trajectory of insubordinated clause (Evans \& Wanatabe 2016)

Within this framework, examples (1) and (2), which have been described as autonomous speech acts whose interpretation does not rely on context, would belong to the final stage of insubordination ${ }^{8}$. Prima facie, they look like the constructions that Lombardi (2004: 206) calls "free conditionals", in which the semantico-pragmatic function of the former main clause has been by convention incorporated into the former subordinate. ${ }^{9}$ However we will see in the next section that the reconstruction of the process leading to this final step raises some problems.

\subsection{Reconstruction problems}

\subsubsection{The si tu savais clause}

We argued in the preceding sections that we have good synchronic reasons to prefer a split analysis of the construct rather than a protasis for a missing apodosis. In this section we will present additional evidence against a diachronic analysis of the si insubordinate as the reanalyzed protasis of an understood apodosis. The only semantically and syntactically possible apodosis would be a declarative clause like tu serais étonné 'you'd be surprised':

(44) Si tu savais ce que moi j'étais contente tu serais étonné

'If you knew how I was glad you'd be surprised'

This will result in unexpected differences between the full construction with the apodosis, and the reduced insubordinate pattern that has been analyzed as an instance of an exclamative clause by applying the tag test. Indeed the full pattern reacts as a declarative clause type with respect to the same test, as in (45-46), in contrast to the reduced pattern, as in (7-11).

(45) à mon avis si tu savais ce que j'étais contente tu serais étonnée

'in my opinion if you knew how happy I was you would be amazed'

si tu savais ce qu'il m'a dit tu serais étonnée tu sais

'if you knew what he said to me you would be amazed you know'

\footnotetext{
${ }^{8}$ See the analysis of Patard (2014) on si and Saez (2014) on quand.

${ }^{9}$ We had also presented this analysis in Debaisieux, Deulofeu \& Martin (2008).
} 
It would not be easy to explain how the integration of a declarative clause in the subordinate clause results in a shift of illocutionary force from assertive to exclamative, including a change in prosodic contour. Moreover, even if we could succeed in building such an explanation, we would still have to face the problem of the outcome of a free-standing exclamative after the insubordination process. Both problematic issues disappear if we posit that the construction has involved stance framing, with no apodosis, from the beginning. This hypothesis is supported by the existence of such a construction with voir as early as the end of the $12^{\text {th }}$ century written style as noticed by Buridan (2000):

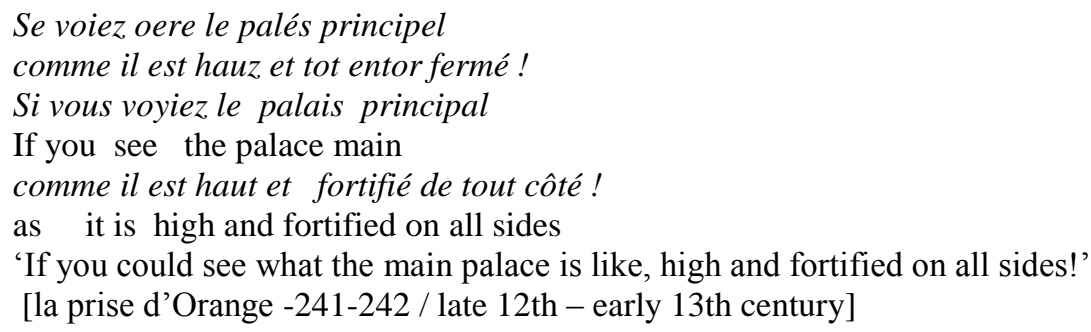

It is perfectly possible to apply a parenthetical + main clause analysis to the construct, since le palés principel comme il est hauz et tot entor fermé! ' the main palace as it is high and fortified on all sides' is a possible exclamative main clause and Se voiez oere 'If you see' a possible evaluative frame.

From synchronic as well as diachronic evidence we are led to conclude that it is more economical to consider the construction as a genuine exclamative main clause and not resulting from the emancipation of a former subordinate clause. The situation may be different for the quand je pense insubordinates, which are dealt with in the following section.

\subsection{The quand je pense clause}

In order to trace the path of the insubordination process of quand je pense clauses, two types of events in Old French are useful to consider. The first concerns the status of temporal constructions, the second, the role of quand. On the first point, the properties of segments that were analyzed lead us to link them to the comment of Combettes (2013: 112) who emphasizes the independence of constructions introduced by quand with simultaneity value in Old French:"This loose dependency [of the time clause] allows us to consider the link between the clauses as a paratactic one." As evidence, he adduces a set of facts that undermine an analysis of the clause as an integrated adjunct: the lack of subject-verb inversion, and the fronted position with insertions of root constituents before the main clause, as we can see in this example from the $15^{\text {th }}$ century translated into modern French:

(48) Quant je pense, lasse au bon temps,

Que me regarde toute nue

Quelle fuz quelle devenue

Et je me voy si tres changee,

Povre, seiche, maigre, menue,

Je suis presque toute enraigee. 
Quand je pense hélas au bon temps

'When I think alas about the good time

Et que je me regarde toute nue

And when I look at myself naked

Comment étais-je, que suis-je devenue

How I was, how I became

Et je me vois si changée

And I see myself so changed

Pauvre, sèche, maigre, menue,

Poor, dry, thin, shrivelled'

[VILLON, LE TESTAMENT, 1461, p. 54]

We can indeed notice after the subordinate clause, the interjection lasse! 'alas!' the direct discourse quelle fuz, quelle devenue 'what was I, how (ugly) have I become' and above all the coordination conjunction $e t$ 'and' before the main clause. All these facts highlight "the autonomous status of the quant clause, assuming, from the point of view of information structure, the role of a topic setting a discourse frame". As regards the status of quant, Combettes (2013:116) signals: "What occurs can be considered as a weakening of the subordinating nature of quant towards various discursive functions; in argumentative discourse, quant loses its temporal value to take the function of a topic marker; in narratives, it no longer conveys a temporal modification of the predicate, but signals a new step in the narrative line".

This comment nicely applies to the grammatical status and to the discourse orientation of the construction quand je pense in contemporary French. We noticed above that it syntactically introduces a grammatically independent clause and that the clause, emancipated from grammatical integration, becomes free to fulfill a range of pragmatic functions depending on the discourse context. In a narrative context, the clause sets a transition frame between two different steps in the main line of the narrative. In an argumentative sequence, it is used to shift to a new discourse topic. The shift to a new topic, achieved by means of a metadiscursive use of quand is explicitly assumed by the speaker via the epistemic je pense, (while I am saying P, it occurs to my mind that Q). This move brings out a subjective contrast between the situation evoked by the quand je pense clause and the one described in the preceding context. This contrast triggers a positive or negative emotion from the speaker, which is frequently expressed by an exclamative clause like "I can't believe it!" Such association can be a step towards the integration of the 'exclamative' stance into the quand je pense clause itself. Quand je pense que becomes a conventionalized way to project an exclamative meaning.

Nevertheless, the looseness of the link between the "subordinates" and the following clauses cast doubt on the claim that the construction is the result of the integration of the exclamative meaning of a former main clause in the quand clause and that it is "a subordinate clause that has been nativized as main clause" (Evans 2007: 375). To make it plausible, we have to imagine a step previous to the reanalysis as a main clause in which the link between the two constructions strengthens from pragmatic dependency to grammatical subordination. Such a transformation may indeed have occurred according to the following comment of Combettes (2013: 123). "During the transition between middle and preclassical French, clauses whose former status was close to parataxis became involved in the network of 
grammatical dependency between subordinate and main clause, subject more to syntactic rules than to loose discourse patterns."

This step would provide the suitable starting point for the regular process of insubordination: quand subordinate + main clause. We could then revise the insubordination path like this, inserting a new Stage 0 and modifying Stage A from that given in Figure 4:

\begin{tabular}{|l|l|l|l|l|}
\hline & $\begin{array}{l}\text { Gramaticalization } \\
\text { Subordination }\end{array}$ & Ellipsis & $\begin{array}{l}\text { Conventionalized } \\
\text { ellipsis }\end{array}$ & $\begin{array}{l}\text { Reanalysis as main } \\
\text { clause structure }\end{array}$ \\
\hline Stage 0 & Stage A & Stage B & Stage C & Stage D \\
\hline $\begin{array}{l}\text { Weak } \\
\text { dependence }\end{array}$ & $\begin{array}{l}\text { Process of } \\
\text { grammaticalisation } \\
\text { leading to } \\
\text { Subordinate } \\
\text { construction }\end{array}$ & $\begin{array}{l}\text { Ellipsis of } \\
\text { main } \\
\text { clause }\end{array}$ & $\begin{array}{l}\text { Restriction of } \\
\text { interpretation of } \\
\text { ellipsis material }\end{array}$ & $\begin{array}{l}\text { Conventionalized main } \\
\text { clause use of formally } \\
\text { subordinate clause } \\
\text { (Constructionalization) }\end{array}$ \\
\hline
\end{tabular}

Fig. 5. A new historical trajectory for insubordinate clause

But this revision is undermined by the fact that the exclamative stance does not need to be expressed by means of a clausal syntactic frame. We indeed find examples starting from Middle French such as:

(49) Quand je pense à vos jambes nues, le matin, deux et trois heures pendant que vous écrivez, mon dieu! Ma bonne, que cela est mauvais!

'When I think of your bare legs in the morning, two and three hours while you are writing, my God! My dear, how bad is this !'

[SÉVIGNÉ Mme de, Correspondance : t. 2 : 1675-1680, 1680, p. 710]

up to contemporary French, through Classical French:

(50) Quand je pense qu' il était possible que cet argent $m^{\prime}$ ê̂t été redemandé !

Au lieu de venir à son secours, il eût fallu lui annoncer... Ah! Dieux!..

'When I think that it was possible that this money would have been asked again of me! Instead of coming to his aid, he would have had to tell him ... Ah! Ye Gods!'

[BEAUMARCHAIS Pierre-Augustin Caron de, Les Deux amis ou le Négociant de Lyon, 1770, p. 110]

In those examples there is no possible governor for the subordinate. A better way to properly capture all these facts is to assume that the basis for the process of integration is not a canonical sentence pattern, comprising adjunct clause + main clause, but a pragmatic routine relying on the following discourse pattern: sudden subjective awareness of a strong contrast between two situations, plus entailed exclamation (whatever its syntactic frame might be). Within this approach, we must anyway assume a further step to deal with the facts that depart from the ongoing analysis: those in which quand je pense or si tu savais combines with a main exclamative clause and those in which quand je pense is an isolated clause, as in (51):

(51) Quelles maîtresses, mon Dieu !... Et Jenkins pour seul protecteur... Oh! quand je pense... Quand je pense...

'What mistresses, my God ... And Jenkins as sole protector ... Oh! When I think... When I think' [DAUDET Alphonse, Le Nabab, 1877, p. 574] 
To deal with these facts, we can resort to a further emancipation of the segment quand je pense as an interactive discourse marker endowed with exclamative function, inviting the addressee to infer from the context the source of the exclamation. There is however a caveat: this use needs a deeper corpus investigation both to clarify its formal status - since, from our limited set of examples, it appears more constrained than si tu savais - and to specify its usage scope.

\subsection{Interim conclusion}

A synchronic analysis, possibly complemented by a diachronic insubordination analysis, may contribute to a better understanding of the difference between the uses of si tu savais and the quand je pense clauses. These overall syntactic analyses can be matched with different plausible pragmatic organizations: the first clause of the paratactic si tu savais and quand je pense patterns is used as a pragmatic marker transferring to the addressee the attitude expressed in an associated exclamative cause. In the insubordinate pattern, quand je pense que functions as a marker of the exclamative force of the clause.

The pragmatic analysis of the grammatically independent "subordinates" is possible along these lines. But there remains an important syntactic issue to address: the relationship between the 'dependent clause' and the main clause in both patterns have till now been defined only negatively as "pragmatically" dependent clauses which are not integrated in the grammatical structure of the main clause. Is there something positive that we can say about this kind of loose dependency in syntactic terms? In order to give a positive answer to this question, we must address a more general one: what exactly is the relationship between syntactic entities and the text units into which we can segment the discourse?

\section{The maximal syntactic unit: sentence or utterance?}

The analysis in Evans (2007) aims at regularizing the apparently irregular syntactic patterns of insubordinate clauses by resorting to the assumption that at some point in the language development all the formally subordinate clauses were also subordinate in syntactic structure, that is governed by the "main" verb. Due to diachronic processing of pragmatic routines guided by a principle of economy the subordinate clauses appear presently as main clauses.

A first problem for this analysis is that on empirical grounds it is impossible to maintain that the subordinating use and the grammatically independent use were not coexistent in spontaneous speech at an early stage of language development. Indeed, Indoeuropeanists take the opposite stance when they argue that subordination is derived from paratactic uses of clauses. The Classical Latin subordinator si is said (Meillet \& Vendryès, $1924 \S 803)$ to have evolved from what was in early Latin a free adverbial to an integrated conjunction. ${ }^{10}$ But it is simply impossible to choose on empirical grounds between the two hypotheses. A diachronic explanation, which is necessarily based only on written evidence, is undermined by the lack of early-stage spontaneous speech evidence. We all know that written styles are far from giving a direct access to all possible structures of contemporary languages.

\footnotetext{
${ }^{10}$ See Deulofeu (2003) for a more detailed presentation.
} 
This lack of evidence is a fortiori true for earlier stages. The first consequence of this limitation of the data to written styles is the assumption that the sentence is the maximal unit for syntactic description. But this assumption cannot satisfy those who describe spontaneous spoken corpora. As pointed out by Mithun (2008: 99):

"If our syntactic analyses are based uniquely on single sentences constructed or elicited in isolation, we may miss some of the subtleties of the syntactic structures we are trying to understand, even in languages with literary traditions."

On theoretical grounds, Halliday (1985:193) points out the need of new units in order to overcome the shortcomings of a sentence-based approach:

"The clause complex will be the only grammatical unit which we shall recognize above the clause. Hence there will be no need to bring in the term 'sentence' as a distinct grammatical category. We can use it simply to refer to the orthographic unit that is contained between two stops".

Following this line is the criticism of Mithun (2005), who insists on the fact that it is impossible to segment folk narratives into sentences. The clause complexes that emerge are better considered as paragraphs.

The need for text units distinct from the sentence pattern is empirically confirmed by the findings of the C-Oral Rom project (Cresti et al 1996). A manual segmentation of 400,000 words based on explicit prosodic and pragmatic criteria reveals that only $66 \%$ of the resulting units fit the canonical sentence model centered on a main clause. The remaining text units are built on many kinds of phrases, each of them with its specific illocutionary force. Similar results emerge from Chapter 14 'Grammar of conversation' of Biber et al. (1999): the socalled non-clausal text-units constitute one third of the segmented utterances in the sample corpus.

The text units correspond indeed to one of the uses of the term 'utterance', i.e. roughly stretches of discourse that are syntactically independent and prosodically and semantically autonomous. The notion of utterance as a synonym of text unit is widely accepted to designate a turn made up of non-clausal material, because it signals that a non-clausal syntactic phrase (e.g. the adverb forward) 'unexpectedly' plays the part of a main clause (Forward!) instead of being a mere constituent integrated in a clause as in I am moving forward (Culicover \& Jackendoff, 2005:236-8). But if the text unit is clause-like, it is useful to make the distinction between a clause as a pure syntactic frame and an utterance, that is a clausal syntactic frame endowed with illocutionary force. Yet the difference can be still related to a clear formal property: a clause is a syntactic unit integrated into a construction without an independent prosodic contour, an utterance is a syntactic unit endowed with an autonomous prosodic contour.

Yet it is possible to adopt descriptive frameworks in which text units or utterances may appear to be built upon non-clausal as well as clausal frames. Here descriptive linguists would replace the assumption of the sentence as the maximal syntactic unit by an alternative one: (almost) any word or phrase or combination of phrases can form a syntactic frame for building a text unit with the appropriate prosodic contour. A main clause, on this account, is just one type of text unit among many possible ones, namely the one that is based on a 
construction headed by a finite verb. We will now elaborate on this new perspective to show precisely how a model constructed on these assumptions can deal with the examples analyzed in this chapter. However, first we need to make one more step to capture the syntactic structure of spontaneous discourse: we must go beyond text units and move on to discourse units.

\section{1. From text units to discourse units}

Discourse is usually reduced to a concatenation of utterances, which amounts to saying that the building blocks of discourse, in other words utterances, are necessarily formed by means of a syntactic unit, be it clausal or non-clausal. But the actual units that speakers use to convey messages to their addressees go far beyond these forms. Addressees also accept messages without syntactic units. Some of them retain phonetic segments, such as interjections, or onomatopoeias. They certainly have phonetic substance, but are not integrated into the grammatical system of the language. Other messages have no phonetic content and consist of what we may call communicative behaviors: mimics or gestures. The last step is to include discourse units with no symbolic form at all. They consist of pieces of meaning derived by inferences from what has been said by the speaker.

Berrendonner \& Groupe de Fribourg (2013), Blanche-Benveniste (1990), Deulofeu (2008), and Debaisieux (2013) claim that it is possible and necessary to capture the combinatorial regularities of discourse units in a separate component of the linguistic description (macro-syntax) and to articulate these regularities with the rules of syntax in the narrow sense (micro-syntax) in order to describe properly the way in which messages are processed. At the microsyntactic level syntactic units (phrases and clauses) combine into larger units according to grammatical dependency rules. At the macrosyntactic level, discourse units, i.e. utterances (syntactic frames endowed with prosodic contours) and communicative behaviors, combine according to the regularities of what Mithun (2005) calls pragmatic dependency. We will focus on the easiest combinations to capture, that is, those between discourse units based on symbolic frames, and especially relevant to our argument here, clause frames.

\subsection{Typology of discourse units}

It is indeed possible to define two types of clause based on utterances according to their internal structure as well as their combinatorial possibilities: free units ('Nuclei') and discourse dependent units ('Satellites'). A Nucleus can stand by itself as an autonomous freestanding message. As for its internal composition, the nucleus is by default a construction endowed with illocutionary force. This property that we code by the feature [+illoc] may be assigned to the various clause types (declarative, interrogative and exclamative) to the extent that they bear a range of conclusive prosodic contours. The combination of clause types and conclusive contours yields various types of nuclei, whose illocutionary force (assertive, interrogative injunctive...) is coded here by punctuation marks:

\footnotetext{
Il est arrivé / Il est arrivé ? / il est arrivé !

'He arrived' / 'has he arrived ?' he has arrived!'
} 
To sum up, the Nucleus is essential for the processing of discourse: it may constitute a complete message, acknowledged as such by the addressee, and can assume various speech functions (Verstraete 2007) according to its specific terminal prosodic contour. This central unit may be accompanied by one or several Satellites, which can be considered as discursively or pragmatically dependent on the Nucleus, since they cannot by themselves form a free standing message but need to be grouped with a Nucleus to be properly interpreted. As regards their internal composition, the Satellite bears the feature [-illoc] irrespective of whether it is realized before or after the Nucleus. The [-illoc] feature codes the fact that the construction displays a non terminal contour and that, in case of a satellite introduced by a conjunction, no sentence type variation is possible (55'):

If we take the default option of a weakly constrained interface between syntactic entities and discourse units we predict that there is no one-to-one correspondence between the types at the respective levels. (52) shows that a declarative clause type can be endowed with all the major speech functions, (53) that syntactic units introduced by a conjunction such as quand can function as main clauses, and (54) that some syntactic frames are specialized in conveying specific speech functions.

The clear cut distinction we make between microsyntax as the domain of grammatical dependency and macrosyntax as the domain of discourse dependency is a radical answer to the issue of the grammatical status of so called extra-clausal constituents (Kaltenböck 2016).

Within this framework, we propose to analyze examples like si tu savais ce que moi j'étais contente as a macrosyntactic combination of the Satellite si tu savais pertaining to the subclass of stance markers such as tu vois, tu imagines... . and a Nucleus ce que moi j'étais contente. This nucleus is an instance of a subclass of exclamative Nuclei introduced by ce que, comme, que...). . Examples like (2) quand tu penses que euh en $1978+80 / 82$ l' agneau on le vendait 34 francs le kilo à la carcasse are analyzed as a macrosyntactic Nucleus based on a construction introduced by a complex marker (Verb + Que complementizer). This configuration groups together a relevant number of members formed by the association of an entrenched verb phrase and a complementizer (est-ce que 'is it that', c'est que 'it is that', dire que 'to say that', c'est à dire que 'that is to say that', ça veut dire que 'it means that'... The complex marker is in turn embedded into a metadiscursive nonintegrated quand clause. Indeed quand is just one among several conjunctions able to introduce clauses performing metadiscursive functions, such as parce que 'because', bien que 'although', puisque 'since', (Debaisieux 2007).

To account for the switch from metadiscursive satellite to nucleus status, we propose to extend the insubordination model by allowing the incorporated material to be a 
macrosyntactic Unit, that is an exclamative Nucleus instead of a grammatical structure: a main clause. In this specific case, the basis of the process is a discourse pattern that can be traced back to a pragmatic routine. Quand je pense behaves as an instructional marker to reconstruct an exclamative stance about the propositional content of the clause, without reference to a particular "main" syntactic frame. Our claim is that such an extension is the best way of capturing the descriptive generalizations.

\section{Conclusion}

In Section 1, we provided a detailed corpus-based analysis of the prosodic, syntactic, semantic, and pragmatic properties of the si clauses and the quand "insubordinate" clauses in French. In Section 2, we showed that the two constructions differ in various ways. The type of example 1 with si clause and some cases with quand je pense clauses can be analyzed as a configuration wich associate a main exclamative clause with a parenthetical clause functioning as a pragmatic marker. The type of example 2 quand je pense que complex clause is related to metadiscursive clauses fulfilling the pragmatic function of establishing a new topic. In Section 3, we compared Evans' solution to our own analysis. In Section 4, we presented our framework and showed that the apparent "insubordinates" are instances of regular syntactic patterns. For the si tu savais clause, it seems more economical to consider that the whole construction does not result from the emancipation of a former subordinate clause. As for the quand je pense que case, the insubordination model helps to reach explanatory adequacy but needs to be extended to conventionalization of discourse patterns instead of resorting to reduction of grammatical structures.

We have been providing a tentative typology of the syntax of discourse relations based on explicit criteria that allow us to challenge the descriptions couched in terms of the standard insubordination model. But we are aware that for the specific problem of insubordination the choice of a solution should not be a matter of theoretical preference. It should be defended both on empirical grounds and on the basis of its comparative complexity. We hope we have outlined the solution that best captures the descriptive generalizations presented in earlier sections.

\section{References}

Berrendonner, Alain \& Groupe de Fribourg. 2013. Grammaire de la période. Berlin, Bruxelles: Peter Lang.

Biber, Douglas, Stig Johansson, Geoffrey Leech, S. Conrad and Edwin Finegan. 1999. Longman Grammar of Spoken and Written English. London: Longman.

Blanche-Benveniste, Claire. 1990. Le français parlé, études grammaticales. Paris: Editions du CNRS. Coll. Sciences du langage.

Buridant, Claude. 2000. Grammaire nouvelle de l'ancien français. Paris :SEDES.

Combettes, Bernard. 2013. Quelques aspects de la «subordination» en ancien et moyen français », in Debaisieux (dir) Hermes Lavoisier, Paris.Corminboeuf, Gilles. 2009. L'expression de l'hypothèse en français contemporain, entre hypotaxe et parataxe. Bruxelles: de Boeck-Duculot. 
Cresti, Emanuella \& Moneglia, Massimo. (ed) 1996, C-ORAL-ROM: Integrated Reference Corpora for Spoken Romance Languages, Amsterdam/ Philadelphia: John Benjamins Publishing Company.

Culicover P. \& Jackendoff R., 2005. Simpler Syntax. Oxford: UP.

Debaisieux, Jeanne-Marie. 2007. La distinction entre dépendance grammaticale et dépendance macrosyntaxique comme moyen de résoudre les paradoxes de la subordination. In Faits de Langue 28: 119-132. Paris: Ophrys.

Debaisieux, Jeanne-Marie. (dir.), 2013. Analyses linguistiques sur corpus. Paris: Hermès Lavoisier.

Debaisieux, Jeanne-Marie. 2016. Toward a global approach to discourse uses of conjunctions in spoken French. In Oliver Ehmer, Dagmar Barth-Weingarten (eds). Adverbial Patterns in Interaction. 79 - 94. Language Sciences 58. Elsevier.

Debaisieux, Jeanne-Marie \& José Deulofeu. 2001 Grammatically unacceptable utterances are communicatively accepted by native speakers, why are they ? In Disfluency in Spontaneous Speech. Proceedings of DiSS '01, ISCA tutorial and Research Workshop, University of Edinburgh, Scotland, 69-72.

Debaisieux Jeanne-Marie, Deulofeu, José, Martin Philippe. 2008. Pour une syntaxe sans ellipse. In Jean Christophe Pitavy \& Michelle Bigot (eds). Ellipse et effacement, 225247. Saint Etienne: P.U.

Deulofeu, José. 2003. L'approche macrosyntaxique en syntaxe : un nouveau modèle de rasoir d'Occam contre les notions inutiles. Scolia 16. Strasbourg: Publications de l'Université de Strasbourg. 47-62.

Deulofeu, José. 2008. Peripheral constituents as generalized hanging topics. In R. Kawajima, G. Philippe \& Th. Sowley (eds), Phantom Sentences, 227-257. Berne : Peter Lang.

Deulofeu, José. 2010. La greffe d'un énoncé sur une construction : une combinaison originale et de rection », La Parataxe T.1 in Marie-José, Beguelin, Mathieu, Avanzi, Gilles, Corminboeuf (eds). Entre dépendance et intégration, 175-208. Berne: Peter Lang.

Deulofeu José 2014. La problématique de la liaison entre prédications à la lumière de la distinction entre construction et énoncé: intégration versus insertion. Langue Française, 182, juin 2014, Paris: Larousse

Deulofeu José 2017. La macrosyntaxe comme moyen de tracer la limite entre organisation grammaticale et organisation du discours. Modèles Linguistiques 2016. 135-166.

Evans, Nicholas. 2007. Insubordination and its uses. In , Irina Nikolaeva (ed.). Finiteness. Theoretical and Empirical Foundations, 366-431. Oxford: OUP.

Evans, Nicholas \&Wanatabe Honore (eds.) 2016. Insubordination. Typological Studies in Language. 115. Amsterdam/ Philadelphia: John Benjamins Publishing Company.

Garrett, Edward 2001. Evidentiality and assertion in Tibetan (Doctoral dissertation, University of California Los Angeles).

Halliday, M.A.K. 1985. Introduction to Functional Grammar. London: Edward Arnold.Lombardi Vallauri, Edoardo. 2004. Grammaticalization of syntactic incompleteness: free conditionals in italian and other languages. Sky Journal of Linguistics, 17, 189-215. 
Kaltenböck, Gunther. 2016. "On the grammatical status of insubordinate if-clauses", in: Kaltenböck, Gunther, Evelien Keizer \& Arne Lohmann (eds.). Outside the clause: Form and function of extra-clausal constituents. Amsterdam: Benjamins, 341-378.

Marandin, Jean-Marie. 2008. The exclamative clause type in French. In S. Müller (ed.) Proc. of the 15th International Conference on HPSG, 436-456. Available online: http://cslipublications.stanford.edu/HPSG/9/toc.shtml

Martin, Philippe. 2009. L'intonation du français. Paris : Armand Colin.

Martin, Philippe. 2014. Spontaneous speech corpus data validates prosodic constraints, in Campbell, Gibbon, and Hirst (eds.) Proceedings of the 6th conference on speech prosody, 525-529.

Meillet, Antoine \& Vendryès, Jules, Traité de grammaire comparée des langues classiques, Paris, Champion.

Milner, Jean-Claude, 1978, De la syntaxe à l'interprétation : quantités, insultes, exclamations, Paris, Le Seuil, coll. «Travaux linguistiques », 1978.

Mithun, Marianne. 2005. On the assumption of the sentences as the basic unit of syntactic structures. In Zygmunt Frayzingier (ed) Linguistic diversity and language theory, 169183. Amsterdam/ Philadelphia: John Benjamins Publishing Company.

Mithun, Marianne. 2008. The extension of dependency beyond the sentence. In Language 83. 69-119.

Patard, Adeline. 2014. Réflexions sur l'origine de l'insubordination. Le cas de trois insubordonnées hypothétiques du français. In Langages 4. 109-130.

Saez, Frédérique. 2014. Découplage de constructions en quand. In Verbum XXXVI, ${ }^{\circ} 1$. 207-233.

Struckmeier, Volker \& Sebastian Kaiser (2015). When insubordination is an artefact (of sentence type theories). Talk at Workshop (Semi-)independent subordinate constructions, 48th Annual Meeting of the Societas Linguistica Europaea, 2-5 September 2015, Leiden.

Tomasello, Michael. 2005. Constructing a language. Cambridge: Harvard University Press.

Verstraete Jean Christophe. 2007, Rethinking the Coordinate-Subordinate Dichotomy. Interpersonal Grammar and the Analysis of adverbial Clauses in English, Berlin, New York: Mouton de Gruyter. 
